\title{
Molecular detection of Anaplasma phagocytophilum in roe deer (Capreolus capreolus) in eastern Poland
}

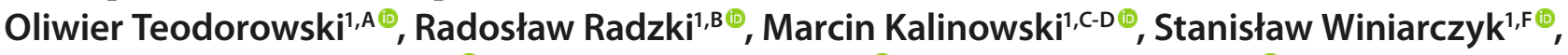 \\ Ignacio Garcia Bocanegra ${ }^{2, \mathrm{E}}{ }^{\oplus}$, Dagmara Winiarczyk ${ }^{1, \mathrm{~B}}{ }^{\oplus}$, Lukasz Adaszek ${ }^{1, \mathrm{~A}, \mathrm{C}, \mathrm{E}-\mathrm{F} \odot}$ \\ ${ }^{1}$ Faculty of Veterinary Medicine, University of Life Sciences, Lublin, Poland \\ 2 University of Cordoba, Spain \\ A - Research concept and design, B - Collection and/or assembly of data, C - Data analysis and interpretation, \\ $D$ - Writing the article, $E$ - Critical revision of the article, $F$ - Final approval of article \\ Teodorowski O, Radzki R, Kalinowski M, Winiarczyk S, Garcia Bocanegra I, Winiarczyk D, Adaszek L. Molecular detection of Anaplasma \\ phagocytophilum in roe deer (Capreolus capreolus) in eastern Poland. Ann Agric Environ Med. 2020; 27(4): 702-705. doi: 10.26444/aaem/124902
}

\begin{abstract}
Wild ungulates may serve as reservoirs for particular tick-borne pathogens (TBP) of importance for public and animal health. The aim of the study was to investigate, for the first time, the occurrence of Anaplasma phagocytophilum (AP) in a large population of roe deer in eastern Poland. Spleen samples from 424 roe deer (Capreolus capreolus) were collected during the 2018-2019 hunting season. Genetic screening for AP was carried out by PCR amplification of a fragment of the 16S rRNA and groEL genes. Twenty-six of the 424 spleen samples (6.13\%) tested positive both for 16S rRNA and groEL. Phylogenetic analysis confirmed the existence of a specific roe deer ecotype of AP in eastern Poland. Despite the low prevalence of AP in roe deer populations in the study area, these animals may act as anaplasmosis reservoirs for ticks. Based on the zoonotic potential of granulocytic anaplasmosis, it seems advisable to introduce continuous monitoring of this infection among domestic, farm and wild animals.
\end{abstract}

- Key words

Anaplasma phagocytophilum, roe deer, Vector-borne disease, Poland

\section{INTRODUCTION}

Tick-borne diseases (TBD) are of increasing importance in veterinary and human medicine [1]. The number of pathogens transmitted by ticks is superior to that of any other arthropod and, in Europe and other temperate zones, are considered the most important arthropod zoonotic vector [2-4].

TBD affect humans and animals, constituting a diversified group of diseases that involve a vast amount of pathogens. However, among these, infections caused by Anaplasma spp., Babesia/Theileria spp., and Borrelia spp. have a noticeable impact. The different species in the genus Anaplasma are a cause of disease in different animals [5], and infections with AP are an emerging human pathogen in Europe and the USA [6, 7]. Anaplasma phagocytophilum is also the most prevalent tick-transmitted animal pathogen [7], responsible for granulocytic anaplasmosis, a disease characterized by fever, weakness, anorexia, thrombocytopenia and occasional lameness in dogs and horses. Ticks and wildlife in general are the main reservoirs of these tick-borne pathogens of human and veterinary interest [8]. Wildlife may play a significant role in the transmission and maintenance of this disease, either acting as reservoirs or amplifying hosts for human or domestic animals [8]. Granulocytic anaplasmosis is transmitted to humans mainly through ticks, but studies by Bakken et al. [9] indicate that direct contact with the blood of animals infected with AP may also result in the development of the disease. The authors of the study described the occurrence of HGA in people working in the processing of deer meat.

Address for correspondence: Lukasz Adaszek, University of Life Sciences, Faculty of Veterinary Medicine, Głęboka 30, 20-612, Lublin, Poland

E-mail: ukaszek0@wp.pl

Received: 18.04.2020; accepted: 02.07.2020; first published: 17.07.2020
The study by Jahfari et al. [10] showed that domestic animals such as horses, dogs and cats, as well as wild animals, such as red deer (Cervus elaphus), wild boars (Sus scrofa), red foxes (Vulpes vulpes) and hedgehogs (Erinaceus spp.), all harbour AP strains with zoonotic potential related to human strains, while roe deer (Capreolus capreolus), rodents and birds seem to carry genetically distant strains

Therefore it is important to characterize the role in the epidemiology of wildlife species in this disease in order to adequately evaluate the potential risks and to design suitable strategies for control.

There is little information about the presence of AP in wildlife in eastern Poland [11-16], thus the aim of this study was to determine the presence of A. phagocytophilum in roe deer in this part of the country.

\section{MATERIALS AND METHOD}

The study was conducted during the 2018-2019 hunting season. Spleen samples $(\mathrm{n}=424)$ were taken from roe deer (Capreolus capreolus) in two provinces: Lublin and Subcarpathia (Tab. 1). The climate of the respective provinces

Table 1. Geographical distribution of provinces where spleen samples were collected

\begin{tabular}{lll}
\hline Provinces & Location & Altitude (above sea level) \\
\hline Lublin & $\begin{array}{l}\text { Situated mainly in the Vistula and Bug } \\
\text { Rivers }\end{array}$ & Highest point - 311 m \\
\hline Subcarpathia & $\begin{array}{l}\text { Located in the south-eastern corner } \\
\text { of the country, characterised by its } \\
\text { diverse natural environment }\end{array}$ & Highest point - 1,346 m
\end{tabular}


is mostly continental: average temperature $-7-8^{\circ} \mathrm{C}$, average annual precipitation $-500-1200 \mathrm{~mm}$, and vegetation period - 180-220 days.

Upon request, necropsy was performed by veterinary practitioners or hunters, and the spleens were collected immediately and submitted for laboratory testing. Samples were stored at $-20^{\circ} \mathrm{C}$ until analysis.

DNA extractions from the spleen samples for molecular testing were performed using a commercial DNA Genomic kit (A\&A Biotechnology Gdańsk, Poland), according to the manufacturer's instructions. All samples were screened for the presence of AP DNA with a polymerase chain reaction (PCR) targeting a $16 \mathrm{~S}$ rRNA AP gene fragment with a size of $932 \mathrm{bp}$, using the primers: ge3a (CACATGCAAGTCGAACGGATTATTC) and ge10r (TTCCGTTAAGAAGGATCTAATCTCC). An initial $5 \mathrm{~min}$. denaturation at $95^{\circ} \mathrm{C}$ was followed by 40 cycles, each consisting of a $30 \mathrm{~s}$ denaturation at $94^{\circ} \mathrm{C}$, a $30 \mathrm{~s}$ annealing at $55^{\circ} \mathrm{C}$, and a 1 min extension at $72^{\circ} \mathrm{C}$. A single $5 \mathrm{~min}$. extension at $72^{\circ} \mathrm{C}$ followed the last cycle. Nested amplifications used $1 \mu \mathrm{l}$ of the primary PCR product as the template in a total volume of $50 \mu \mathrm{l}$. The primers ge9f (AACGGATTATTCTTTATAGCTTGCT) and ge2 ('GGCAGTATTAAAAGCAGCTCCAGG) were used in the reaction. They enabled the amplification of the product with a size of $546 \mathrm{bp}$. Nested cycling conditions were as described for the primary amplification, except that 30 cycles were used [17].

PCR-16S rRNA positive samples were analysed further with primers targeting a fragment of the groEL gene of AP. EphplgroEL(569)F (ATGGTATGCAGTTTGATCGC), EphplgroEL(1193)R (TCTACTCTGTCTTTGCGTTC), and EphgroEL(1142)R (TTGAGTACAGCAACACCACCGGAA) primers were used in combination to generate a primary and heminested PCR for the selective amplification of 624 and 573 bp of the groEL gene of AP respectively. The PCR was followed by 40 cycles, each consisting of a $30 \mathrm{~s}$ denaturation at $94^{\circ} \mathrm{C}$, a $30 \mathrm{~s}$ annealing at $55^{\circ} \mathrm{C}$, and a $45 \mathrm{~s}$ extension at $72^{\circ} \mathrm{C}$ [18].

As positive controls, the DNA of AP was obtained from the National Reference Centre for Borrelia of the Max von Pettenkofer Institute (Munich, Germany). PCR amplification was performed using a programmable thermocycler (Biometra, Göttingen, Germany). The size of each PCR product was evaluated by electrophoresis in a $1.5 \%$ agarose gel stained with ethidium bromide.

Final identification was performed by sequencing of the PCR products. Purification was performed using QIAquick spin columns (Qiagen) and eluted in $50 \mu$ l of Tris $10 \mathrm{mM}, \mathrm{pH}$ 7.6. DNA sequencing was performed on both strands using the same primers employed for PCR at the DNA Sequencing and Synthesis Service of the Institute of Biochemistry and Biophysics, Polish Academy of Sciences, Warsaw, Poland.

DNA sequences were assembled and edited using SeqMan (DNAStar, Lasergene, Madison, WI, USA) and MegAlign (DNAStar, Lasergene, Madison, WI, USA), with alignments to the published sequences of the 16S rRNA gene of: A. phagocytophilum GU183908 (from horses in Poland); A. centrale, EF520690 (from cattle in Italy); A. marginale AF414876 (origin not known - from Israel); A. ovis AY837736 (from mosquitos in Sweden); A. platys EU439943 (from dogs in Italy), and with alignments to the published sequences of groEL gene (Tab. 2). Phylogenetic analysis (based on the neighbour-joining algorithm method) of the obtained sequences was performed using MegAlign software.
Table 2. Sequences of AP groEL gene used in the study

\begin{tabular}{lcc}
\hline Host & Origin & Accession No. \\
\hline horse & USA & AF172158 \\
\hline horse & USA & AF172159 \\
\hline sheep & NO & AF548386 \\
\hline sheep & GB & U96730 \\
\hline human & USA & U96728 \\
\hline human & USA & AF172159 \\
\hline human & SL & AF033101 \\
\hline Dog & SL & EU381150 \\
\hline l.ricinus & SL & EU246960 \\
\hline l.ricinus & IT & KF031386 \\
\hline l.ricinus & SK & KF383237 \\
\hline l.ricinus & AT & AY220467 \\
\hline l.ricinus & IT & KF031388 \\
\hline l.ricinus & SK & KF383240 \\
\hline I.ricinus & DE & AY281827 \\
\hline Roe deer & PL & DQ779568 \\
\hline Roe deer & PL & JN005747 \\
\hline Roe deer & AT & AY220470 \\
\hline volent & RUS & KC5831385 \\
\hline Eurasian shrew & RUS & HQ630617 \\
\hline
\end{tabular}

AT - Austria; DE - Germany; GB - Great Britain; IT - Italy; NO - Norway; PL - Poland; RUS - Russia; SK - Slovakia; SL - Slovenia.

\section{RESULTS AND DISCUSSION}

Twenty-six of the 424 spleen samples tested positive in PCR, with an overall PCR prevalence of $6.13 \%$. The partial $16 \mathrm{~S}$ rRNA gene was sequenced for all 26 positive PCR products and confirmed as A. phagocytophilum. They showed a 99.6$100 \%$ identity with the AP GU183908 sequence obtained from horses in Poland during a previous study [19].

All the DNA samples positive for the 16S rRNA gene also proved positive for the groEl gene. All the groEL sequences generated here were $100 \%$ identical to the groEL sequences of AP from roe deer in Poland (GenBank: DQ779568) and 100\% to groEL sequences of AP extracted from I. ricinus in Slovenia (GenBank: EU246960) (Fig. 1). The groEl sequences obtained in the author's study showed the lowest similarity (94.7\%) with the groEl sequences of AP from rodents (GeneBank KF031385 and KF031390), whereas their similarity with the groEl sequences of AP from humans (GeneBank AF142159, U96728, and AF033101) was 97.9-98.4\%.

The phylogenetic tree for partial groEL genes, including previously published reference samples (Tab. 2), consisted of three main clades. The first clade included ecotypes detected in $I$. ricinus ticks and various vertebrate hosts, such as sheep, horses, dogs and humans. The second clade included only ecotypes detected in roe deer in Poland and Austria, as well as in I. rcinus ticks. The third clade included only ecotypes detected in rodents.

The AP sequences obtained in the study were evaluated as meeting the second clade, which is phylogenetically distant from clades 1 and 3. Wildlife is seen to have increasing importance in the maintenance and transmission of TBD. 
The current study has proved the presence of AP in roe deer in eastern Poland. The presence of these pathogens has also been reported in the blood of wild animals in Europe [13-15, 20-22].

The main reservoir of AP in nature are forest rodents [23] and members of the deer family [24]. Research conducted by Bown et al. [25] in the United Kingdom showed that the period of bacteremia in rodents was short and lasted several weeks, and that the highest frequency of infections with AP was recorded in late summer and autumn. However, infection with AP in deer is long-term and subclinical, and any species of this family may be a reservoir for the bacteriae [7]. The presence of AP has been confirmed in the following: red deer, elk, roe deer and fallow deer [13, 26, 27]. Long-term bacteremia makes the deer a competent reservoir of Rickettsia and contributes to the circulation of the pathogen in nature. In wild ruminants the prevalence of $\mathrm{AP}$ has been found to vary between regions and countries, with values ranging from $10-38 \%$ in roe deer, $10-51 \%$ in red deer, $[13,15,16,28$, 29] and as high as $98.9 \%$ in roe deer infected in Germany [30].

In the current study, the presence of DNA was found only in the spleen of slightly more than $6 \%$ of the studied animals. This prevalence seems to be low in comparison to the prevalence of infections in wild cervids from other parts of Europe, as well as from the north-eastern part of Poland where $38.7 \%$ of roe deer were infected [12]. In other animal species in eastern Poland, the prevalence of AP also seems to be low, and according to studies by Dzięgiel et al. [15, 31] and Adaszek et al. [13], the DNA of this bacteria was found only in $2.75 \%$ of dogs, $14 \%$ of fallow deer and $18 \%$ of wild bison. The explanation for such variability could depend on the distribution of ticks, and hence with ecoclimatic variation.

Another explanation for the low prevalence of A. phagocytophilum in roe deer could be that it was the spleen rather than the whole blood that constituted the material for the study. The choice of spleen as diagnostic material was made on account of the observations by Bown et al. [25], who asserted that the presence of these microbs was more often observed in spleen samples than in the blood. This is due to the late phase of the infection, where the AP passes from the blood vessels to the spleen $[15,25]$. However, in research by Kazmirova et al. [32] and Adamska and Skotarczak [26], the DNA of AP in roe deer was detected mainly in the blood, and only occasionally in the spleen. This may indicate that spleen samples are not good material for the isolation of Anaplasma DNA

It has also been indicated that wild animals are able to control the infection mainly through the activation of innate immune responses, phagocytosis and autophagy, leading to infection levels below PCR detection or infection clearance, which could also have an impact on the low prevalence of Anaplasma in the roe deer in the current study [1, 33, 34]. This study, based for the first time on a large population of roe deer in eastern Poland, shows the presence of AP in these animals. Other Anaplasma species such as A. platys, A. centrale, A. marginale has not been detected in roe deer. These species are transmitted by ticks, such as Rhipicephalus sanguineus and Dermacentor auratus (A. platys); R. annulatus, $R$. decoloratus, $R$. microplus, D. andersoni. D. variabilis and $D$. occidentalis (A. marginale and $A$. centrale), which do not occur in Poland and might explain the lack of DNA of these bacteriae in the spleen samples of the studied animals [35].
All AP isolates obtained in this study were qualified to a single ecotype, differing from the AP ecotypes found in humans, farm animals and domestic animals, as well as from those isolated from rodents, which may indicate that the roe deer in eastern Poland do not constitute a reservoir host for the human pathogenic strains of AP [36].

Information on the prevalence and geographical distribution of AP infections is essential for the effective planning of control measures. These results suggest that game animals may act as reservoirs for Anaplasma, although the zoonotic potential of the AP strains occurring in roe deer is low. Along with the changing climatic conditions and the increasing risk of anaplasmosis in native animals, it seems advisable to introduce continuous monitoring of this infection among domestic, farm and wild animals.

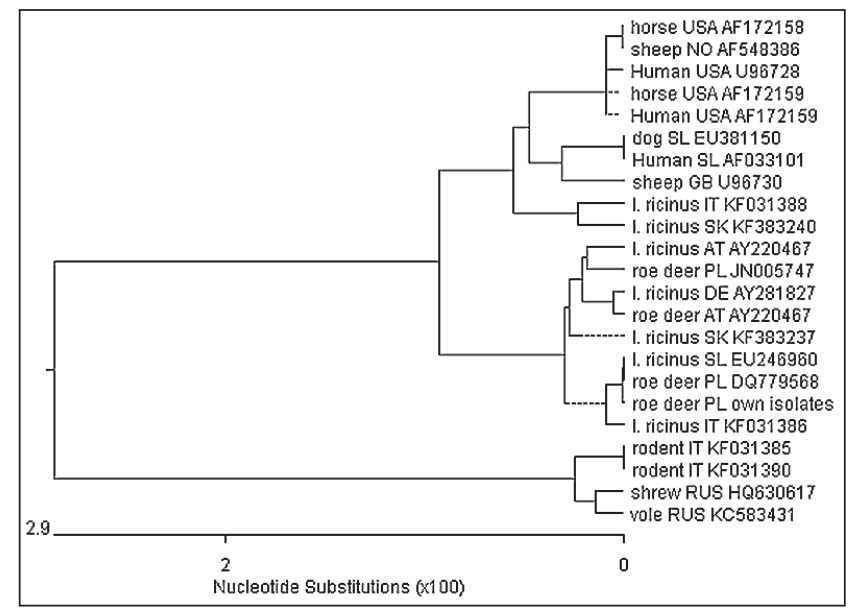

Figure 1. Phylogenetic relationships between AP groEL sequences obtained in the study and deposits in GenBank

\section{Conflicts of Interest}

The authors declare that they have no competing interests. The authors certify that they have no affiliation with or financial involvement in any organization or entity with a direct financial interest in the subject matter or materials discussed in the manuscript.

\section{REFERENCES}

1. Vayssier-Taussat M, Kazimirova M, Hubalek Z, Hornok S, Farkas R, Cosson JF, et al. Emerging horizons for tick-borne pathogens: from the 'one pathogen-one disease' vision to the pathobiome paradigm. Future Microbiol. 2015; 10(12): 2033-2043. https://doi.org/10.2217/fmb.15.114

2. Munderloh U. Comparative studies in tick-borne diseases in animals and humans. Vet Sci. 2017; 4(2): E32. https://doi.org/10.3390/vetsci4020032

3. Asman M, Witecka J, Solarz K, Zwonik A, Szilman P. Occurrence of Borrelia burgdorferi sensu lato, Anaplasma phagocytophilum and Babesia microti in Ixodes ricinus ticks collected from selected areas of Opolskie Province in south-west Poland. Ann Agric Environ Med. 2019; 26(4): 544-547. https://doi.org/10.26444/aaem/110214

4. Mysterud A, Stigum VM, Seland IV, Herland A, Easterday WR, Jore S, et al. Tick abundance, pathogen prevalence, and disease incidence in two contrasting regions at the northern distribution range of Europe. Parasit Vectors. 2018; 11(1): 309. https://doi.org/10.1186/s13071-018-2890-9.

5. Battilani M, De Arcangeli S, Balboni A, Dondi F. Genetic diversity and molecular epidemiology of Anaplasma. Infect Genet Evol. 2017; 49: 195-211. https://doi.org/10.1016/j.meegid.2017.01.021

6. Kocan KM, de la Fuente J, Coburn LA. Insights into the development of Ixodes scapularis: a resource for research on a medically important tick species. Parasit Vectors. 2015; 8: 592. https://doi.org/10.1186/s13071015-1185-7 
7. Dzięgiel B, Adaszek Ł, Winiarczyk S. Wild animals as reservoirs of Anaplasma phagocytophilum for humans. Przegl Epidemiol. 2016; 70(3): 428-443.

8. Dantas-Torres F, Chomel BB, Otranto D. Ticks and tick-borne diseases: a One Health perspective. Trends Parasitol. 2012; 28(10): 437-446. https://doi.org/10.1016/j.pt.2012.07.003

9. Bakken IS, Krueth JK, Lund T, Malkovitch D, Asanovich K, Dumler JS. Exposure to deer blood may be a cause of human granulocytic ehrlichiosis. Clin Infect Dis. 1996; 23(1): 198. https://doi.org/ 10.1093/ clinids/23.1.198

10. Jahfari S, Coipan EC, Fonville M, van Leeuwen AD, Hengeveld P, Heylen D, et al. Circulation of four Anaplasma phagocytophilum ecotypes in Europe. Parasit Vectors. 2014; 15; 7: 365. https://doi. org/10.1186/1756-3305-7-365

11. Rymaszewska A. Divergence within the marker region of the groESL operon in Anaplasma phagocytophilum. Eur J Clin Microbiol Infect Dis. 2008; 27(11): 1025-1036. https://doi.org/ 10.1007/s10096-0080539-x

12. Hapunik J, Víchová B, Karbowiak G, Wita I, Bogdaszewski M, Pet'ko B. Wild and farm breeding cervids infections with Anaplasma phagocytophilum. Ann Agric Environ Med. 2011; 18(1): 73-77.

13. Adaszek $€$, Klimiuk P, Skrzypczak M, Górna M, Ziętek J, Winiarczyk S. The identification of Anaplasma spp. isolated from fallow deer (Dama dama) on a free-range farm in eastern Poland. Pol J Vet Sci. 2012; 15(2): 393-394. https://doi.org/10.2478/v10181-012-0060-0

14. Michalik J, Stańczak J, Cieniuch S, Racewicz M, Sikora B, Dabert M. Wild boars as hosts of human-pathogenic Anaplasma phagocytophilum variants. Emerg Infect Dis. 2012; 18(6): 998-1001. https://doi. org/10.3201/eid1806.110997

15. Dzięgiel B, Adaszek Ł, Krzysiak M, Skrzypczak M, Adaszek M, Furmaga $\mathrm{B}$, et al. The occurrence of Anaplasma phagocytophilum in wild bison from Białowieza Primeval Forest in Eastern Poland. Berl Münch Tierärztl Wochenschr. 2015; 128(7-8): 310-314.

16. Szewczyk T, Werszko J, Myczka AW, Laskowski Z, Karbowiak G. Molecular detection of Anaplasma phagocytophilum in wild carnivores in north-eastern Poland. Parasit Vectors. 2019; 12(1): 465. https://doi. org/10.1186/s13071-019-3734-y

17. Massung RF, Slater K, Owens JH, Nicholson WL, Mather TN, Solberg $\mathrm{VB}$, et al. Nested PCR assay for detection of granulocytic ehrlichiae. J Clin Microbiol. 1998; 36(4): 1090-1095.

18. Alberti A, Zobba R, Chessa B, Addis MF, Sparagano O, Pinna Parpaglia $\mathrm{ML}$, et al. Equine and canine Anaplasma phagocytophilum strains isolated on the island of Sardinia (Italy) are phylogenetically related to pathogenic strains from the United States. Appl Environ Microbiol. 2005; 71(10): 6418-6422. https://doi.org/10.1128/AEM.71.10.64186422.2005

19. Adaszek $€$, Winiarczyk S, Łukaszewska J. A first case of ehrlichiosis in a horse in Poland. Dtsch Tierarztl Wochenschr. 2009; 116(9): 330-334. https://doi.org/10.2376/0341-6593-116-330

20. Hartwig V, von Loewenich FD, Schulze C, Straubinger RK, Daugschies A, Dyachenko V. Detection of Anaplasma phagocytophilum in red foxes (Vulpes vulpes) and raccoon dogs (Nyctereutes procyonoides) from Brandenburg, Germany. Ticks Tick Borne Dis. 2014; 5(3): 277-280. https://doi.org/10.1016/j.ttbdis.2013.11.001

21. Michel AO, Mathis A, Ryser-Degiorgis MP. Babesia spp. in European wild ruminant species: parasite diversity and risk factors for infection. Vet Res. 2014; 45: 65. https://doi.org/10.1186/1297-9716-45-65

22. Messner M, Kayikci FN, Shahi-Barogh B, Harl J, Messner C, Fuehrer HP. Screening of wild ruminants from the Kaunertal and other alpine regions of Tyrol (Austria) for vector-borne pathogens. Parasitol Res. 2019; 118(9): 2735-2740. https://doi.org/10.1007/s00436-019-06412-9
23. Blaňarová L, Stanko M, Carpi G, Miklisová D, Víchová B, Mošanský L, et al. Distinct Anaplasma phagocytophilum genotypes associated with Ixodes trianguliceps ticks and rodents in Central Europe. Ticks Tick Borne Dis. 2014; 5(6): 928-938. https://doi.org/10.1016/j. ttbdis.2014.07.012

24. Kauffmann M, Rehbein S, Hamel D, Lutz W, Heddergott M, Pfister $\mathrm{K}$, et al. Anaplasma phagocytophilum and Babesia spp. in roe deer (Capreolus capreolus), fallow deer (Dama dama) and mouflon (Ovis musimon) in Germany. Mol Cell Probes. 2017; 31: 46-54. https://doi. org/10.1016/j.mcp.2016.08.008

25. Bown KJ, Begon M, Bennett M, Woldehiwet Z, Ogden NH. Seasonal dynamics of Anaplasma phagocytophila in a rodent-tick (Ixodes trianguliceps) system, United Kingdom. Emerg Infect Dis. 2003; 9(1): 63-70. https://doi.org/10.3201/eid0901.020169

26. Adamska M, Skotarczak B. Wild game as a reservoir of Anaplasma phagocytophilum in north-western Poland. Wiad Parazytol 2007; 53(2): 103-107.

27. Jouglin M, Blanc B, de la Cotte N, Bastian S, Ortiz K, Malandrin L. First detection and molecular identification of the zoonotic Anaplasma capra in deer in France. PLoS One. 2019; 14(7): e0219184. https://doi. org/10.1371/journal.pone.0219184.

28. Di Domenico M, Pascucci I, Curini V, Cocco A, Dall’Acqua F, Pompilii $\mathrm{C}$, et al. Detection of Anaplasma phagocytophilum genotypes that are potentially virulent for human in wild ruminants and Ixodes ricinus in Central Italy. Ticks Tick Borne Dis. 2016; 7(5): 782-787. https://doi. org/10.1016/j.ttbdis.2016.03.012

29. Welc-Falęciak R, Werszko J, Cydzik K, Bajer A, Michalik J, Behnke JM. Co-infection and genetic diversity of tick-borne pathogens in roe deer from Poland. Vector Borne Zoonotic Dis. 2013; 13(5): 277-288. https:// doi.org/10.1089/vbz.2012.1136

30. Overzier E, Pfister K, Herb I, Mahling M, Böck G Jr, Silaghi C. Detection of tick-borne pathogens in roe deer (Capreolus capreolus), questing ticks (Ixodes ricinus) and ticks infesting roe deer in southern Germany. Ticks Tick Borne Dis. 2013; 4(4): 320-328. https://doi.org/10.1016/j. ttbdis.2013.01.004

31. Dzięgiel B, Adaszek Ł, Carbonero A, Łyp P, Winiarczyk M, Dębiak P, et al. Detection of canine vector-borne diseases in eastern Poland by ELISA and PCR. Parasitol Res. 2016; 115(3): 1039-1044. https://doi. org/ 10.1007/s00436-015-4832-1

32. Kazimírová M, Hamšíková Z, Špitalská E, Minichová L, Mahríková L, Caban R, et al. Diverse tick-borne microorganisms identified in freeliving ungulates un Slovakia. Parasit Vectors. 2018; 11(1): 495.https:// doi.org/10.1186/s13071-018-3068-1

33. de la Fuente J, Gortazar C. Wild boars as hosts of human-pathogenic Anaplasma phagocytophilum variants. Emerg Infect Dis. 2012; 18(12): 2094-2095. https://doi.org/10.3201/eid1812.120778

34. Galindo RC, Ayllon N, Smrdel KS, Boadella M, Beltran-Beck B, Mazariegos M, et al. Gene expression profile suggests that pigs (Sus scrofa) are susceptible to Anaplasma phagocytophilum but control infection. Parasit Vectors. 2012; 5: 181. https://doi.org/10.1186/17563305-5-181

35. Atif FA. Anaplasma marginale and Anaplasma phagocytophilum: Rickettsiales pathogens of veterinary and public health significance. Parasitol Res. 2015; 114(11): 3941-3957. https://doi.org/10.1007/s00436015-4698-2

36. Matei IA, Estrada-Peña A, Cutler SJ, Vayssier-Taussat M, Varela-Castro L, Potkonjak A, et al. A review on the eco-epidemiology and clinical management of human granulocytic anaplasmosis and its agent in Europe. Parasit Vectors. 2019; 12(1): 599. https://doi.org/10.1186/s13071019-3852-6 